Authors' copy. For citation, please refer the published version. Kumpu, Ville (2013). A climate for reduction? UN climate summits as a context for imagining futures in journalism. Futures 53, 53-62

\title{
Ville Kumpu
}

\section{A climate for reduction? Futures imagined in newspaper coverage of UN climate summits}

\begin{abstract}
This article studies how futures were imagined in newspaper coverage of the UN climate summits in Bali (2007), Copenhagen (2009) and Cancu' n (2010) in the Finnish newspapers Helsingin Sanomat (HS) and Ilta-Sanomat (IS). The study employs a discourse-theoretical perspective to highlight the contingency of representations and the process of meaning making. Articulations of futures are studied in relation to the argument that in climate change debates a sense of predestination, in the form of predictions inferred from climate models, prevails over ways of imagining futures that allow more room for human agency and social change. The "prestige paper" (HS) rated the summits high on its news agenda and covered climate treaty negotiations extensively while the "tabloid"' (IS) provided more sporadic, often celebrity or scandal driven coverage. In both papers, futures were articulated in relation to the climate treaty which functioned as a nodal point in a binary dichotomy between a desired future articulated through emission reductions and an undesired future articulated through consequences of climate change. Beyond the immediate summit context other articulations of futures, relating to uncertainty (HS) and the probability of concrete climate change consequences (IS), emerged.
\end{abstract}

Keywords: Climate change, Climate summits, Journalism, Discourse theory

\section{Introduction}

Climate change has been well established as a driver for change shaping futures in most areas of life and at scales ranging from the individual to the global [see e.g. 24,25,21,17]. Furthermore climate change is in itself an issue that is particularly future-sensitive: for the most part, global worry over the issue (and research deriving from it) is based on predictions, projections and scenarios concerning greenhouse gas emissions, the material consequences of rising greenhouse gas concentrations in the atmosphere, and the social consequences of changes to the earth's climate patterns. While such climate change oriented "future presents" have been studied intensively in future studies and elsewhere, the "present futures", that is, the ways in which futures are imagined in the present, have for the most part been left unexamined ${ }^{1}$. To begin to

\footnotetext{
${ }^{1}$ The distinction between "present futures" and "future presents" was introduced to the social sciences by Niklas Luhmann [1, p. 278-279]. M ore recently, the distinction has been put to use by Barbara Adam and Chris Groves [19]. Luhmann, and Adam and Groves each develop the idea in distinct ways. Luhmann suggests in his study "The Differentiation of Society" that a present future is rooted in a utopian approach which allows for prediction while future present is technologically constituted and, as such, allows us to transform future presents into present presents. Adam and Groves, on the other hand, suggest that the "divergent standpoints involved affect not just our action but also our ethical potential: responsibility for the future requires that we are able to take the stand point of the future present and have the capacity to move knowledgeably between the two approaches" [19, p. 200]. In this article, the distinction is used to refer to the difference in attempts to study how the future will be (future presents) and how the future is imagined in the present (present futures).
} 
fill this research gap, this article examines how futures were imagined in coverage of three recent UN climate summits $^{2}$ in two Finnish newspapers. A starting point for the analysis is climate scientist Mike Hulme's [3] argument that predictive natural sciences and especially climate models ${ }^{3}$ have achieved a hegemonic position in contemporary climate change discourse over more contingent, imaginative and humanistic accounts of social life and visions of the future. For this reason, the future is easily reduced to changes in climate while human agency as well as social and cultural changes that do not easily fit with these models are left unexplored.

[T)his hegemony is rooted in the knowledge claims of climate, or Earth system, models. In the absence of comparable epistemological reach emerging from the social sciences or humanities, these claims lend disproportionate discursive power to model-based descriptions of putative future climates. It thus becomes tempting to adopt a reductionist methodology when examining possible social futures. 'Lots of things will change in the future, but since we have credible and quantitative knowledge about future climate let us examine, also quantitatively, what the consequences of these climates for society might be'. The subsequent and derived climate impact modelling then boldly calculates, for example, the billions of people who because of climate change will become starving or thirsty, or the millions who because of climate change will be made destitute or homeless. Climate reductionism is the means by which the knowledge claims of the climate modellers are transferred, by proximity as it were, to the putative knowledge claims of the social, economic and political analysts. [3, p. 262,263]

Futurist Sohail Inayatullah $[2,4]$ has divided future studies research into three overlapping categories: predictiveempirical, cultural-interpretive and critical post-structural, each with their differing assumptions about reality, truth, the future and agency. According to Inayatullah [2, p. 115] the predictive-empirical approach "simply reinscribes the present even while it 'predicts' the future". While attempting to discern how different cultures have perceived the future in different times, the cultural-interpretive approach manages to relativize the future, but according to Inayatullah, at the expense of politics. The framework he advances instead is "critical post-structural" that attempts to establish distance from current categories of knowledge concerning the future "that allows us to see current social practices as fragile, as particular, and not as universal categories of thought" [4, p. 816]. The task then is "not so much to better define the future but rather at some level to 'undefine' the future" [4, p. 816]. While the study at hand examines strictly present futures and does not thus attempt anything like causal layered analysis (CLA) [see e.g. 4], a futures technique developed by Inayatullah, the article shares the critical, post-structural and constructivist viewpoint.

\footnotetext{
${ }^{2}$ By "climate summits" the article refers to Conferences of the Parties (COP) of the United Nations Framework Convention on Climate Change (UNFCCC) that entered into force in 1994. The first COP was organized in 1995. ${ }^{3}$ By climate models Hulme [3] refers to computer-based simulation models of a universal and globally connected climate system (developed since the 1960s) which allow experiments with global models that are not possible in physical reality and must thereby be performed in virtual reality. According to Hulme, by the late 1980s (as the models became more and more complicated, representing besides the atmosphere or the climate system the deeply coupled components of the Earth system) the way climate was understood had changed from varied conceptions of climate used by geographers, climatologists and synoptic meteorologists toward a more uniform idea that climate is the outcome of the functioning of an interconnected biogeophysical global system whose past, present and future behavior could be modeled and hence predicted.
} 
A discourse-theoretical framework provides a solid starting point for an analysis from such a standpoint [see e.g. 18,5-10]. The approach derives from the work of political theorists Ernesto Laclau and Chantal Mouffe [11-14] but it has also been developed as an applicable approach for media research $[15,16]$. In discoursetheory, the discursive is a theoretical horizon that highlights the linguistic and symbolic nature of reality, in other words, the discursive component of reality is emphasized without equating discourse and reality $[15, \mathrm{p}$. 267]. From such a position anything meaningful is unavoidably discursive. Discourse-theory is antiessential: no pre-given, self-determining essence capable of fully determining the meaning of things is assumed. Every sign or element has an infinite number of potential meanings which derive from the way they are articulated as connected to other signs and differing from each other. Discourses are about the reduction of possibilities; they are "attempts to stop the sliding of the signs in relation to one another and hence to create a unified system of meaning" [6, p. 27]. Discourses are produced in the process of articulation that establishes a relation among elements such that their identity is modified" [11, p. 105]. While generally speaking discourse-theory highlights the fluidity of meaning, it does not claim that anything can mean anything. In practice, possibilities of signification are always socially limited. The discursive attempt to fix meaning is both impossible (because the field of meaning is infinite, re-articulations are always possible) and necessary (because without the fictitious fixing of meaning there would be no meaning at all). In the effort to achieve this fixity nodal points are essential: "nodal points are the privileged signs around which other signs are ordered; the other signs acquire their meaning from their relationship to the nodal point'” [6, p. 27].

To approach climate change from a discourse-theoretical perspective means, to begin with, acknowledging that the material processes of climate change do not define its signification. From this perspective, climate change in itself does not demand action but rather its coerciveness derives from its connection to other signifiers such as the survival of the human species or sustaining the contemporary standard of living. The process of signification is far from a meaningless language game since the ways in which issues are constructed have profound (often material) consequences. To give two brief examples, the construction of climate change as "the greatest threat facing humanity" may be helpful in emphasizing the gravity of the issue and creating "climate consciousness" but, at the same time, due to the global spread of such consciousness more and more issues, ranging from poverty to biodiversity loss, have become articulated in relation to climate change, as parts of the problem to be solved. This potentially creates "a political log-jam of gigantic proportions, one that is not only insoluble, but one that is perhaps beyond our comprehension", [17, p. 333]. In a similar fashion, the position weather has assumed in climate change debates is highly problematic. Again, while the instant articulation of any weather event considered "unusual" or "extreme", in relation to human induced climate change may be regarded as useful in creating awareness and promoting change and responsibility, it is also problematic as it implies a change from "natural weather" toward "human weather", weather co-produced by a natural-cultural climate system. This often translates into misleading debates concerning the extent to which a given phenomena can be attributed to human action or 
to the equally misleading idea that there has been a stable "natural climate" that has now been disrupted and which could be reinstated if proper action is taken [3].

The future, in contrast to climate change, is defined by its lack of materiality in the present and therefore its signification cannot be (even theoretically) defined by its material dimension. Following the work of social scientists Barbara Adam and Chris Groves [19], two basic dimensions for imagining futures ${ }^{4}$ can be identified: one based on the belief that the future already exists in the present time (future predestined) and the other based on the belief that futures are constantly created in the present (open future). The former includes all kinds of divine foreordaining and other forms of determinism, highlighting the role of destiny, fate, cosmic forces, and the laws of nature in determining what the future will be. To imagine such a predestined future one must consult whatever is posited as in control of the future which leads to various forms of divination and prophecy but also to certain forms of scientific investigation as ways of imagining futures. In the case of the open future, it is individuals and humanity in general who own and shape the future with their actions. From this perspective, the ambitions, goals and capabilities of agents in the present form the basis for imagining futures.

From a discourse-theoretical perspective, highlighting the importance of the process of meaning making, this article studies how futures were imagined in coverage of three recent UN climate summits in two Finnish newspapers. The analysis is situated in relation to the argument [3] that a sense of predestination, in the form predictions inferred using climate models, prevails in climate change debates over ways of imagining that allow more room for human agency and social change. UN climate summits represent the most pronounced effort to tackle climate change politically. The summits force different kinds of actors, forms of knowledge and visions of the future into a compressed time-space, functioning as moments of visibility and exposure which enables a kind of a global scrutiny of societies and their leaders that is not possible in normal circumstances [20,21]. Media coverage of climate change can be considered as one of the key contributors that shape climate change policy discourse as well as action. To begin with the public garners much of its knowledge about climate change from mass media. Mass media processes significantly shape how actors, issues, events, pronouncements and information are perceived. Media representations shape the issue of climate change by articulating it in relation to some other issues while leaving others disconnected. Thus, a boundary is constantly drawn between what is relevant in relation to climate change and what is not. Furthermore, in media coverage legitimate actors are identified and their legitimacy further increased with their appearance in media $[22,23,26,27]$. While certainly justified and fruitful, the focus on newspaper coverage of climate summits imposes important restrictions as well. The summits and the kind of compressed time-space they create is a specific instance in the general climate change debate and media

\footnotetext{
${ }^{4}$ In the article, the concept of imagination is used because it highlights the nature of knowledge of the future as a construction that despite often appearing in the guise of empirically based predictions cannot be empirically grounded. Imagination is used when referring to the overall process of imagining futures while specific instances or ways of imagining are referred to as constructions or discourses.
} 
coverage of the issue. This specificity undoubtedly affects the ways in which futures are imagined. The article explores this specificity by identifying the fundamental features of summit coverage based on an extensive research project on the topic and discussing their relation to imagining futures in the analysis. A clear limitation is that of all the media available only newspapers coverage was studied. Without denying these limitations, it can be noted that despite the turmoil in the media industry in the past two decades newspapers have a relatively strong position in the Finnish media landscape compared to countries like the United States, for example 5 . In addition, the narrow focus on newspapers allows the article to compare futures imagined in two different kinds of newspapers that reflect a rough division between "prestige" or "elite" and "popular" or "tabloid" newspapers. The main research questions of the article are: (1) how were futures imagined in the coverage of three recent climate summits in two Finnish newspapers? (2) how do these futures imagined differ between a "prestige newspaper" and a "popular paper"'?, and (3) how does the way in which futures were imagined relate to the argument that a sense of predestination, taking the form of predictions inferred using climate models, prevails in climate change debates?

\section{Materials and methods}

The material of this study consists of coverage of the climate summits in Bali (COP 13, 2007), Copenhagen (COP 15, 2009) and Cancun (COP 16, 2010) in the Finnish newspapers Helsingin Sanomat (HS) and IltaSanomat (IS) (see Table 1$)^{6}$.

Table 1. The newspaper coverage of three climate summits in two Finnish newspapers.

\begin{tabular}{|l|l|l|l|l|}
\hline & Bali & $\begin{array}{l}\text { Copenhagen } \\
(2007)\end{array}$ & Cancún & Total \\
& $(2009)$ & $(2010)$ & \\
\hline Helsingin Sanomat & 69 & 168 & 57 & 294 \\
\hline Ilta-Sanomat & 24 & 48 & 3 & 75 \\
\hline
\end{tabular}

The material can be broadly defined as news but 12 editorials, 33 columns or comments by journalists, and 46 letters to the editors were included as well. HS is the only daily newspaper in Finland that can claim true national reach. With such a position and unrivaled resources the paper has a relatively strong agenda-setting function among both the political elite and other media. While HS can be described as a subscription based

\footnotetext{
${ }^{5} 78 \%$ of Finns claim to have read a newspaper during the previous day (34 min expended on average daily) [37]. ${ }^{6}$ The material was collected within the following timeframes: December 1st-22nd 2007/2009 (Bali and Copenhagen), November 24th-December $15^{\text {th }} 2010$ (Cancu' $n$ ). It includes all journalistic material (including letters-to-the-editor) that concerned the summit or climate change in general published in the print version of the newspapers.
} 
prestige paper, IS is one of two Finnish tabloid newspapers sold exclusively on newsstands. Both papers (as practically all daily newspapers in Finland) are politically unaffiliated by their own declaration ${ }^{7}$.

Methodologically the article relies on content analysis [see e.g. 28] and a discourse analysis based on a constructivist, post-structural framework [see e.g. 18,5-10,15,16]. In the former case, the article builds on the effort of the MediaClimate network to explore and compare the coverage of climate summits across the world [29,20,30,31]. Connected to this effort the coverage of HS and IS was analyzed using a coding scheme that classified the genre, size, location of the stories and people quoted in the stories ${ }^{8}$. In this article information derived from the content analysis and from the previous studies is used to contextualize the empirical analysis presented by describing the general features of summit coverage in HS and IS. The analysis of futures imagined in the coverage is based on discourse analysis that aimed through close reading of the material to identify discourses concerning the future from the material ${ }^{9}$.

\section{Climate summits and climate change coverage}

In Finland, environmental issues have been relatively well recognized and merged with the mainstream political agenda since the emergence of the environmental movement in the 1970s. As a major environmental problem, climate change emerged in Finland in the late 1980s and early 1990s [32,33].

According to public opinion polls, the general public has been considerably worried over the issue though in recent years the worry expressed in polls has been in decline ${ }^{10}$. As a member of the European Union, Finland is committed to the internal burden of sharing cuts in greenhouse gas emissions as well as to other targets of climate politics.

\footnotetext{
${ }^{7}$ HS has a circulation of 337962 (2012), IS 132253 (2012). The population of Finland is 5420981 (2012). Both papers are owned by the same company, Sanoma Oyj. In an international comparison the journalistic difference between the papers can be elaborated using media scholar Colin Spark's [38] five step categorization. HS can be described as a "semi-serious" newspaper (cf. The Guardian in the UK), IS as "serious-popular" (c.f. USA Today in the US, Daily M ail in the UK) $[38,39$, p. 288]. However, in the Finnish context these papers represent the extremes as there are no daily newspapers that fit the extremes of Spark's categorization ("serious" and "newsstand tabloid press").

${ }^{8}$ The coding scheme and coding instructions have been published in the first volumes produced by the network [29].

The coding of the Finnish material was conducted by the author of this article between 2009 and 2011.

${ }^{9}$ Technically the analysis was conducted in three steps. First, as a part of the content analysis, every story was classified according to whether it was future-oriented or not and whether references to explicit years in the future were made. Any reference to a future exceeding the immediate context of the summit was considered as a future orientation. Secondly, future-oriented aspects of the coverage were analyzed to begin to answer the question of how futures were imagined in relation to conceptions of a predestined future and an open future. Thirdly, with a preliminary understanding of the future discourses in the material considered as future-oriented, the whole material was scrutinized to reveal possible gaps in the earlier analysis concerning more subtle or implicit references to the future.

10 In a 2006 national survey commissioned by the Finnish business policy forum (EVA), a pro free market policy think tank, 86 per cent of the respondents agreed (fully or somewhat) with the statement "climate change is the greatest threat of our time and action to prevent it should be taken immediately in all countries". In 2004, the corresponding figure was 79 per cent, 66 per cent in 2010, and 71 per cent in 2012 [40,41]. In a poll commissioned by Helsingin Sanomat, 82 per cent of the respondents rated climate change as a "great" or "reasonably great" threat in 2007 while in 2009 the corresponding figure was 63 per cent (HS September 15th 2010: "Worry over climate has faded").
} 
In HS the volume of yearly climate change coverage was stable, between one hundred and two hundred stories from 1995 to 2003 (see Fig. 1) ${ }^{11}$. The number of stories doubled in 2004 and almost tripled between 2006 and 2007 reaching a peak at 1188 stories. This time period can be described as the time of "climate hype" [34]. The peak was followed by a steep decline in coverage and in 2011 the volume of coverage had returned to a pre-peak level. Climate summits have been steadily covered in HS (see Fig. 1). Bali and Copenhagen summits are two notable peaks (the latter against the general decline in climate coverage).

Figure 1. Climate change and climate summits in Helsingin Sanomat.

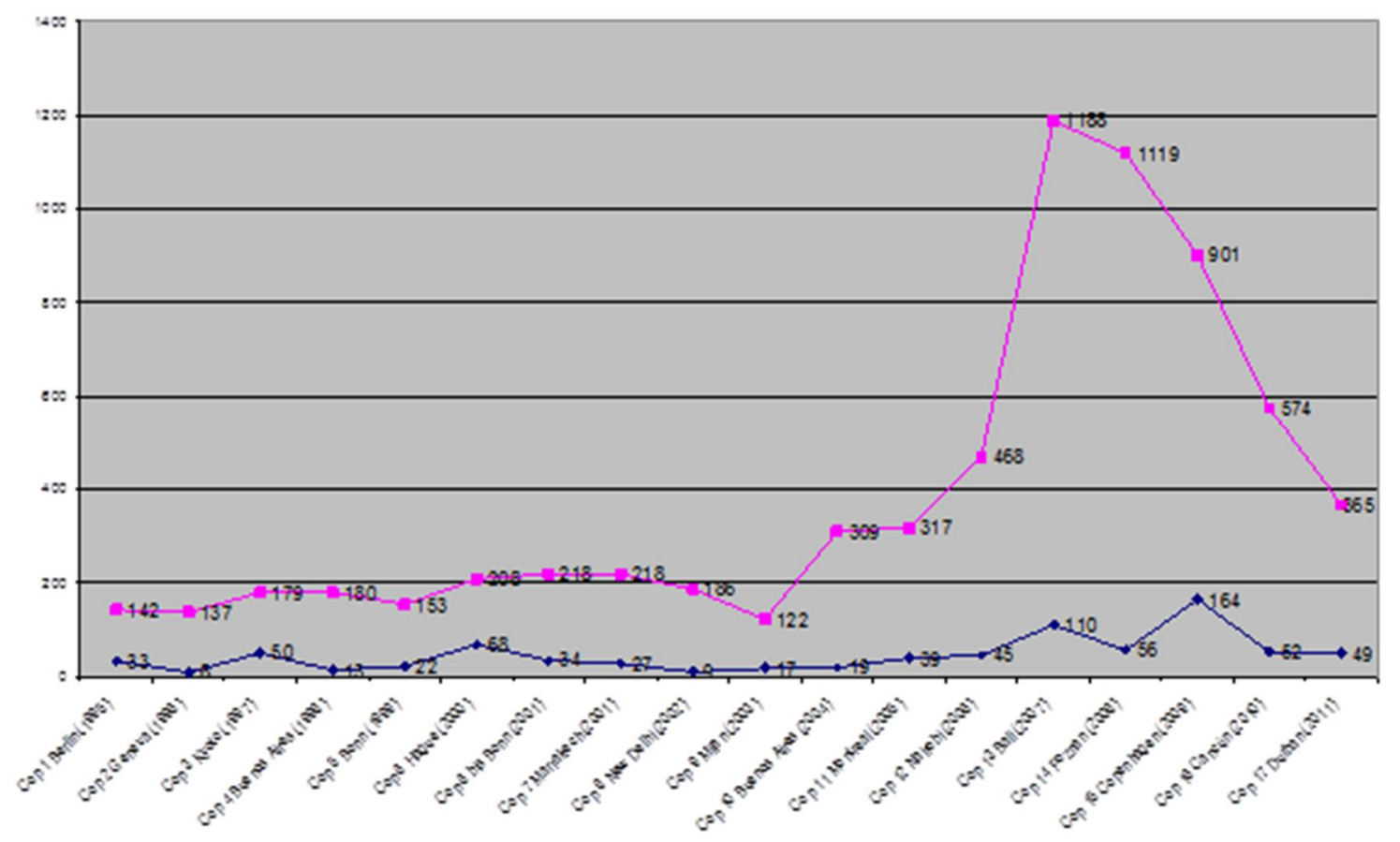

Next the response of each newspaper to the climate summits as news events is briefly explored to contextualize the qualitative analysis presented in this article. In HS the volume of coverage was significantly greater than in IS (see Table 1). In IS there was practically no news coverage of the Cancun summit. HS had one correspondent present in Bali and three in Copenhagen. The correspondents contributed substantially to the coverage in HS: $15 \%$ of all the stories in the case of Bali and $37 \%$ in the case of Copenhagen were written by correspondents at the scene. IS had no correspondents present at any of the summits and its coverage relied significantly more on news agencies. In HS columns, comments written by

\footnotetext{
${ }^{11} \mathrm{Fig} .1$ is based on a keyword search of the electronic archive of HS. Unfortunately, the same type of information on IS is not available. Given its position in the country, the volume of coverage in HS can serve as a rough indicator of the evolution of the issue in Finland. In the search, the keywords "ilmastonmuutos" (climate change) and "ilmaston la"mpeneminen" (global warming) were used. The search was performed on M ay 2nd 2012 and it includes all journalistic material (including letters-to-the-editor) published in the print version of the paper. In the search results every combination of title and text was considered as a separate story. In the case of the volume of summit coverage presented in Fig. 1 the keywords used were "ilmastonmuutos" (climate change), "ilmaston la"mpeneminen" (global warming) and "kasvihuoneilmio" " (greenhouse effect) and the timeframe used was three days before and three days after each summit.
} 
journalists (and especially the correspondents) were a prominent feature of the coverage whereas in IS such commentary was nonexistent.

Two kinds of actors dominated coverage in both papers ${ }^{12}$ : politicians representing nation-states and civil society actors (representatives of environmental organizations, activists, demonstrators and people interviewed for vox pop pieces) comprised $65 \%$ of the people quoted (see Table 2). The former represented the more dominant share of actors ranging from $41 \%$ (Bali) to $29 \%$ (Cancun). Particularly in HS, where the role of politicians was in general somewhat more prominent, their significance was further emphasized in news stories, front pages stories, and as people quoted at the beginning of news stories. In IS transnational political actors (e.g. people representing the UN) were not quoted at all. While demonstrations organized at the summit sites and elsewhere were eagerly covered in HS, in IS their coverage was dependent on the occurrence of clashes between police and demonstrators, for example ${ }^{13}$. In IS celebrities such as $\mathrm{Al} \mathrm{Gore} \mathrm{and}$ Arnold Schwarzenegger had a substantial role in the coverage. In both papers the role of climate (and other) science was relatively subdued. While keeping in mind that the material consists of stories from journalistic genres ranging from editorials to letters to the editor, it can be noted that a considerable part of the material did not quote anyone, directly or indirectly (40\% of stories) ${ }^{14}$. In HS $15 \%$ (45) and in IS only $5 \%$ (3) of the stories had three or more people quoted.

From the perspective of the quantitative study, the "dialog potential" [35] of the summit coverage was quite weak. The most common combination of actors transcending the actor-categories was a politician representing a nation-state and a civil society actor which appeared in six stories ( $2 \%$ of the material). Most

\footnotetext{
${ }^{12}$ All individuals quoted directly or indirectly in the coverage were noted (e.g. the UN was only considered an actor when someone representing it was quoted). In a story, the same individual was only counted as an actor once, even if quoted several times. If two individuals representing the same organization or institution were quoted, they were counted as separate actors (thus, it was possible for the same organization to appear as an actor several times in one story). Actors were classified in five main categories and 26 sub-categories according to their "institutional background". The main categories were "national political system" (representing a particular nation-state), "transnational political system" (e.g. the EU, the UN), "civil society" (NGOs, activists, citizens), "business" (e.g. entrepreneurs) and "science and expertise" (e.g. climate scientists). Every actor was also classified in terms of gender and in relation to being Finnish or foreign.

${ }^{13}$ The difference between the papers was most clearly manifest in their coverage of the climate march organized during the Copenhagen summit. In HS it was reported as the central item on the front page and referred to as a "good-humored public festival" (HS Dec 13th 2009, title of a front page story, with picture). The report continued inside the paper with a whole page assemblage of stories (with eight pictures of demonstrators and activists) celebrating the atmosphere and highlighting the demands made ("Climate march demanded extensive action", "The atmosphere here is unbelievable", "What message would you like to send from the Copenhagen demonstration?"). In IS the same event was covered with stories concentrating on the clashes between police and activists (IS Dec 14th, "The end of a convivial atmosphere" and "A man from Helsinki locked-up: cruel treatment").

${ }^{14}$ One reason for the quite high share of stories with no actors is that all combinations of title and text were considered as separate items in the quantitative study (for example, fact boxes, columns or comments that do not rely on quotes as strongly as news stories).
} 
commonly a story that quoted someone quoted one politician (10\%) or one civil society actor (9\%). The most common combination within the actor-categories was two politicians representing nation-states $(4 \%)^{15}$.

Table 2. Institutional background of people quoted in the summit coverage of HS and IS.

\begin{tabular}{|l|l|l|l|l|}
\hline & $\begin{array}{l}\text { Bali } \\
(\mathrm{N}=103)\end{array}$ & $\begin{array}{l}\text { Copenhagen } \\
(\mathrm{N}=252)\end{array}$ & $\begin{array}{l}\text { Cancún } \\
(\mathrm{N}=73)\end{array}$ & $\begin{array}{l}\text { Total } \\
(\mathrm{N}=428)\end{array}$ \\
\hline National political system & $41 \%$ & $39 \%$ & $29 \%$ & $38 \%$ \\
\hline Transnational political system & $4 \%$ & $7 \%$ & $5 \%$ & $6 \%$ \\
\hline Civil society & $22 \%$ & $31 \%$ & $22 \%$ & $27 \%$ \\
\hline Business & $12 \%$ & $3 \%$ & $1 \%$ & $5 \%$ \\
\hline Science, expertise & $18 \%$ & $16 \%$ & $34 \%$ & $20 \%$ \\
\hline Other & $3 \%$ & $4 \%$ & $8 \%$ & $5 \%$ \\
\hline
\end{tabular}

The empirical study presented here can be situated in a Finnish national context where climate change as a problem is well acknowledged among the political elite and the general public but the issue is not contested in domestic politics. As such the context differs radically from national contexts where climate change or the climate treaty are highly contested topics in domestic politics [e.g. Canada, see 42, or Australia, see 43, 44]; where the issue of climate change is not established at all [e.g. Russia, see 45]; or where the potential impacts of climate change are severe [e.g. Bangladesh, see 46, 47]. In each paper the response to climate summits as news events differed [for a more detailed analysis, see 36]. HS invested significantly in providing coverage and commentary on the summits. In IS the summit coverage was more dependent on the position of climate change as a popular talking point and on spectacular dimensions of the summit such as celebrities or clashes between police and demonstrators. At both newspapers the editorial position (as expressed in editorials in the material of this study) toward the UN summits or curbing climate change in general can be considered as sympathetic. The difference between HS and IS reflects a more general difference between coverage of climate summits in prestige and popular newspapers: the former are more likely to rate the summits high on their news agenda, while in the latter their position is often more unstable [29,30].

\section{The climate treaty as a nodal point for imagining futures}

In HS the summits were articulated as decisive moments and the climate treaty as the solution to climate change and thus as the desirable direction of (climate) politics. The future was articulated in a binary dichotomy between a desirable future deriving from the treaty and an undesirable future deriving from the

\footnotetext{
${ }^{15}$ An important limitation of this type of study of the potential of journalism to create dialog is that the unit of analysis in the quantitative study was a single story. The tendency in modern (Finnish) journalism is to report major issues in several hierarchical stories. Thus a story may quote only one politician, for example, as this is the point of the story. The story may then be placed next to a separate story presenting the view of an environmentalist. However within this context and especially within stories quoting several sources, the analysis provides interesting and relevant information.
} 
inability to establish it. Despite the failure of the negotiations to achieve a binding treaty, in the case of all three summits, there were no calls to halt the negotiations (even non-permanently). The hope of establishing a treaty was actively sustained in HS editorials published before, during, and after summits.

If the UN climate summit in Nairobi a year ago could be described as a revivalist meeting, the forthcoming summit at Bali could be called a summit of the eleventh hour. It is characterized by the feeling of time running out. ("Climate summit at Bali characterized by difficult negotiations", Dec $3^{\text {rd }}$ 2007.)

Despite all the hesitation, maneuvering and difficulties the negotiators have one great benefit at their side: a strong will to stop global warming. Everyone knows that if the Copenhagen summit fails, the climate will is going to wither and the window of opportunity will be lost. ("A world to be changed in two weeks", Dec $6^{\text {th }}$ 2009.)

Already Saturday many were reminded that a complete standstill was avoided and that now it can be stated that there is worldwide unanimity that climate change is a threat that must be stopped. In this respect the difference is great compared to the situation that prevailed a year ago, for example. Climate negotiations are a process that proceeds step by step. ("Obama declaration was a bitter disappointment", Dec 20 2009 .)

The Cancun summit can be viewed as a step towards a new climate treaty. However, the actualization of such a treatyat the summit in South Africa next year requires a lot of work from the negotiators of different countries and also a genuine will to compromise on the part of both superpowers and developing countries. There is not a lot of time and the task is difficult, but not impossible. ("The agreement in Cancun was good climate news", Dec $\left.14^{\text {th }} 2010.\right)$

The hope manifested in the editorials was articulated in relation to an undesirable future that would derive from the inability to establish a treaty. Such a future was articulated through a wide range of unwanted physical and social consequences of climate change. In this consequence discourse, the warming of Arctic regions, the destruction of rainforests, the collapse of Inuit hunting culture, sinking islands, melting glaciers, rising sea levels, heat, droughts, heavy rains and coastal flooding were all articulated as flowing from the inability to reach a consensus over emission reductions. The consequences were available for journalists without references to any kinds of authority (such as climate science) as illustrated in the comment written by a correspondent at the scene of the summit (from this perspective the relatively small role of climate - and other - scientists in the coverage is also notable).

Talk won't do it anymore. This Tuesday, indigenous peoples, whose lives are directly influenced by the warming of Arctic regions and the destruction of rainforests, presented their concerns in Copenhagen. For example, the whole basis for Inuit hunting culture is in danger of collapsing as Arctic ice melts. Solomon Islands, the homeland of Maylen Sese, are about to be drowned. The melting rate of glaciers and Arctic sea ice has accelerated. The sea level is projected to rise 30 centimeters in a hundred years. Developing countries dependent on agriculture are already suffering from heat, droughts and heavy rains. Coastal flooding has become more common in Finland. The we have not caused anything attitude is dangerous. Curbing climate change requires a change of lifestyle. ("No time to hesitate", HS Dec $9^{\text {th }} 2009$, comment by a correspondents at the scene of the summit.)

The treaty was the desirable future articulated in the coverage of HS. Beyond the hope of it being established prominently illustrated in the editorials it was articulated through emission reduction targets. In a stark contrast to the consequence discourse, the future in this reduction discourse was articulated using highly precise language and quantified expressions to articulate the difference between the present and the desired future.

Industrial countries should reduce their emissions by 25-40 percent from the 1990 levels and developing countries 15-30 percent by the year 2020. By the year 2050, global emissions should be crunched by 50 percent 
which in developed countries means emission reductions at a scale of 80 percent. ("Climate treaty is a challenging target', HS Dec $7^{\text {th }} 2009$, news story.)

In IS the articulation of summits as decisive moments and the treaty as the solution to climate change was not as prominent as in HS as the coverage was less focused on the negotiations specifically. Celebrity or scandal driven stories such as the ones covering the arrival of Al Gore to Copenhagen (IS Dec 8th 2009) or clashes between police and demonstrators (IS Dec 14th 2009) concentrated on the present or immediate past rather than futures related to climate change. However, when the summit and the negotiations were covered, the binary dichotomy between a desirable future articulated through specific emission reduction targets and the undesirable future articulated through the unwanted consequences of climate change emerged. Two stories published in IS during the Copenhagen summit illustrate the position of the negotiations in the coverage. A half page story with two pictures reported the disagreement between then Governor of California Arnold Schwarzenegger and Republican politician Sarah Palin ("Big-Arnie vs. Palin - the climate quarrel”, IS Dec 18th 2009). Below a smaller story reported on the status of the negotiations by highlighting a disagreement on emission reduction targets between the US and China.

The US has suggested cuts that would be 17 per cent below the 2005 level by the year 2020. According to these mathematics only a three per cent reduction would be achieved compared to 1990 while China's demand is 40 per cent. ("Obstacles in making a deal: USA and China", IS Dec $18^{\text {th }} 2009$, news story.)

The consequence discourse was most prominently illustrated in IS after the Copenhagen summit in a story connecting the weak results of the summit to the fate of the Maldives amidst rising sea levels.

One and a half degrees and not a bit more. That is as much as the global average temperature can rise, according to small island states. For them, the weak compromise crafted at the Copenhagen summit this Saturday was a great disappointment. "If the temperature rises even a little over one and half degrees the Maldives and many other small and low-lying islands may be lost, commented Maldives' president Mohamed Nasheed after the summit. ("The beginning of the end?", IS Dec $21^{\text {st }} 2009$, news story.)

The articulation of the future in the context of the climate summits points to the powerful position of the climate treaty in structuring the way futures are imagined. Particularly in HS where the treaty was articulated as the factor of separation between a desired future and an undesirable one. In the reduction discourse future was articulated as open to human influence and knowable through explicit and quantified targets for emission reductions. In the consequence discourse, future was articulated as predestined. A wide range of physical and social consequences were articulated as deriving from the inability to establish a climate treaty. The binary dichotomy of futures structured around the treaty in the coverage described above illuminates a hegemonic way of imagining futures. However, in stories about climate change published during the summits but not explicitly connected to it, other articulations of the future emerged.

\section{Futures beyond the treaty}

During the summits HS and IS published stories about climate change which did not refer to the summits and which were not published alongside the summit coverage. In HS such stories discussed the consequences of climate change within the context of Finland. In contrast to the consequence discourse that articulated 
undesired futures in the summit context, the uncertainty of specific consequences was highlighted. This was illustrated in a news story reporting on a research project of the Finnish Forest Research Institute ${ }^{16}$.

Forecasting the consequences of climate change in forest ecosystems is difficult because of the complicated ecological interactions involved. The growth rate of forests is likely to increase. On the other hand, the damages caused by fungal diseases are likely to increase as winters become milder and precipitation increases. If freezing is rare or non-existent, the eggs of some pest insects will survive through winter and increase the risks of destruction. ("Warming climates change Finnish forests and scenery", HS Dec $3^{\text {rd }}$ 2007, news story.)

Distance from the articulation of the summits as decisive moments allowed more room for critical interpretations of the targets articulated as a desirable future in the reduction discourse. At the summits, HS correspondents highlighted the significance of the treaty in their columns and comments with titles like "No time to hesitate" (Dec $9^{\text {th }}$ 2009), “From words to action" (Dec 15 ${ }^{\text {th }} 2007$ ) and “The victory of reason" (Dec $12^{\text {th }} 2010$ ). The work done by home desk journalists in the same genre but disconnected from the summit coverage was distinctly more critical. Although the legitimacy of the treaty negotiations was not questioned, individual details relating to it, such as the relation between burning wood and carbon sinks or the false pride over meeting the Kyoto emission reduction targets, were critically scrutinized ${ }^{17}$.

The uncertainty articulated in HS was not evident in IS stories that had no direct connection to the summit. In IS these climate stories articulated the future in relation to the catastrophic or peculiar consequences of climate change, which were used as starting points for news stories. The articulation of futures in IS also leaned more toward the exact probabilities of concrete events than on uncertainty. A story about climate change and snowy Christmases is a case in point ${ }^{18}$ :

The likelihood of black Christmases will increase in the future if the temperature increases even by a little. On average, snow only falls in the south of Finland on December 24th. In Helsinki, there is snow on every other Christmas. "The probability of black Christmases increases in the future, says meteorologist Jouko Korhonen from the Finnish Meteorological Institute. ("The end of snowy Christmases?'” IS Dec 17th 2007, news story.)

While direct summit coverage produced similar articulations of climate change futures in both papers examined here, at a distance from the summit context the future was articulated distinctively in both papers. In HS the binary dichotomy between a desirable future articulated through emission reductions and an undesirable future articulated through the physical and social consequences of climate change was contrasted

\footnotetext{
${ }^{16}$ The uncertainty of specific consequences was articulated in a similar fashion in stories such as "Climate change is taking grain crops and oil plants toward northern Finland (HS Dec $5^{\text {th }}$ 2007) and "Global warming will bring recurrent coastal floods to Finland" (HS Dec 11 ${ }^{\text {th }}$ 2007).

17 "A solution to climate change that is too easy" (HS Dec 22th 2009), "EU spells trouble" (HS Dec 4th 2007), "Oras Tynkkynen yearns for wind power instead of assumptions" (HS Dec $3^{\text {rd }} 2009$ ), "The emission reduction targets of Helsinki are too modest" (HS Dec 7th 2009), "A small problem with carbon sinks" (HS Dec $7^{\text {th }} 2009$ ), "Bargain politics for climate" (HS Dec 10 $10^{\text {th }}$ 2009), "Burning wood is not without emissions" (HS Dec11th 2009), "Burning stumps is a sin after all"' (HSDec $3^{\text {rd }}$ 2010).

${ }^{18}$ Similar articulation of the future was manifest in stories about Al Gore's false claims concerning the melting of ice at the North Pole ("Don't exaggerate Al", IS Dec 12th 2007), the "extinction of girls" due to the effect warming may have on the sex of babies being born ("Warming threatens girls", IS Dec 17 ${ }^{\text {th }} 2007$ ), the melting of Himalayan glaciers ("Summit meeting", IS Dec 5th 2009), and an iceberg split from Antarctica that was trailing toward Australia ("Giant ice berg approaching!", IS Dec 12 $2^{\text {th } 2009) . ~}$
} 
with a discourse of uncertain consequences in the case of Finland. In IS peculiar or catastrophic climate change futures were highlighted and articulated through the exact probabilities of concrete events.

\section{Conclusions}

In coverage of the UN climate summits in Bali (COP 13, 2007), Copenhagen (COP 15, 2009) and Cancu' $n$ (COP 16, 2010) in Finnish newspapers Helsingin Sanomat (HS) and Ilta-Sanomat (IS) the future was imagined as a binary dichotomy between a desired future articulated through emission reductions and an undesired future articulated through the physical and social consequences of climate change. The summits were articulated as decisive moments and the climate treaty as the factor separating these two futures. This was the hegemonic way of imagining futures in the immediate summit context in spite of the differing interpretations of the summits as news events in both papers. At a distance from the immediate summit context, in stories that were about climate change but not about the summit, each newspaper imagined futures differently. In HS the future was articulated in relation to the uncertainty of specific consequences in the context of Finland while in IS peculiar or catastrophic climate change futures were highlighted and articulated through the exact probabilities of concrete events.

The climate treaty functioned as a nodal point that structured the ways in which futures were imagined in the summit context. Especially in HS where the hope of a treaty and the articulation of summits as decisive moments rendered the treaty inevitable and naturalized the direction of (climate) politics. While such an articulation and focus may be considered helpful in creating the moral pressure required to establish a treaty, its hegemony also necessarily excludes other articulations of climate politics and horizons for action. The power of the treaty as a nodal point in the coverage was such that its legitimacy as a direction for climate politics was directly challenged only once ${ }^{19}$. No futures for climate politics beyond the treaty were articulated in the coverage. The direct summit coverage of HS especially was bound by the objectives of the summits that were deemed important. A critical distance from these targets was more easily achieved by home desk journalists at HS who were not directly responsible for covering the summits. In parallel, the futures in the direct context of the summit were articulated in relation to the treaty as the factor separating a desired and an undesired future, while beyond the immediate summit context articulations of the future overriding the treaty emerged.

The constructivist viewpoint of this article responds to the need to put considerably more emphasis on reflecting what climate change is doing to us and what it can do for us culturally rather than focusing solely on what we can do for the physical reality of anthropogenic climate change [17]. While in public discourses climate change is often interpreted from a realistic and normative perspective that highlights the issue as a

\footnotetext{
${ }^{19}$ The challenge was articulated in a quote published during the Copenhagen coverage in a "voice of the day" column that presented short quotes from people involved with the summit. In the column (Dec 18th 2009) titled "Zombie gathering" the "Danish statistician and skeptical environmental critic Bjorn Lømborg" was said to be "waiting for the failure of the negotiations" which would "allow a true change of track" toward "more radical investments" in green technologies.
} 
problem to be solved, the discourse-theoretical view applied in this article highlights the contingency of such an interpretation. To study climate summits from this perspective involves accepting that the articulation of anthropogenic climate change as a physical process, with a moral imperative that defines its signification, must be explored as one (albeit highly powerful) discourse among others with no privileged position. In the coverage of the summits studied in this article the hegemony of the moral imperative of climate change reduced the futures related to the issue to a binary dichotomy between a desired future of emission reductions and an undesired future of climate change consequences; two outcomes set apart by the specific political act of establishing a climate treaty.

From this perspective the argument that a kind of a climate reductionism with climate increasingly presented as the cause defining the fate of humanity has emerged with the heightening of anxieties about climate change [3] did resonate, in many ways, with how climate summits were covered in the two papers. Firstly, solving climate change was reduced to establishing a climate treaty. Secondly, the diversity of futures related to climate change and the variety of human approaches to those futures were reduced to a binary dichotomy between a desired future articulated through emission reductions and an undesired future articulated through physical and social consequences of climate change. Thirdly, in the consequence discourse the fate of humanity was reduced to the consequences deriving from changes in the climate. The future was articulated as predestined by the inability to establish a treaty on emission reductions. Furthermore, the change articulated between present day and future was an intensification of the relationship between the climate and human agency. A changing climate was not articulated as a variable defining wars, migration or economic growth as a phenomena existing in the present time (or in the past) but it was articulated as vigorously shaping them in the future. Fourthly, in the reduction discourse future was reduced to emission reductions. The possibility of a preferred transformation was articulated but such a future was not imagined beyond the quantitative descriptions of emission reductions. In both discourses the abstract laws captured by climate models were articulated as defining what the future will be like and the future of humanbeings was reduced to the functioning of the Earth's climate system. Finally, at least in the case of HS, the summit context clearly reduced the ability of or willingness of journalists to imagine alternative futures.

The articulation of the future as a binary dichotomy between a desired future of emission reductions and an undesired future of climate change consequences can certainly make the correct option appear self-evident. The idea of a solution to climate change is a powerful one and in contemporary discourses it is articulated in relation to a wide variety of things. One of the most prominent articulations of a solution are the UN climate summits and the climate treaty. The analysis in this article shows that in terms of imagining futures the consequences of such an articulation are substantial - as summarized above in relation to climate reductionism. From a wider perspective, the question then is whether the articulation of climate change as "a mega-problem waiting for a mega-solution", [17, p. 333] and the restricted ways of imagining futures related to it are the best way to build a durable relationship with it. Asking such a question does not mean adhering 
to "skeptical" or "denialist" positions that attempt to curb any action on climate change but rather means taking the cultural dimension of climate change seriously.

\section{References}

[1] N. Luhmann, The Differentiation of Society, Columbia University Press, New York, 1982.

[2] I. Sohail, Deconstructing and reconstructing the future: predictive, cultural and critical epistemologies, Futures 22 (1990) 115-141.

[3] M. Hulme, Reducing the future to climate: a story of climate determinism and reduction, Osiris 26 (2011) 245-266, 2011.

[4] I. Sohail, Causal layered analysis: poststructuralism as method, Futures 30 (1998) 815-829.

[5] J. Torfing, Discourse theory: achievements, arguments, and challenges, in: D. Howarth, J. Torfing (Eds.), Discourse Theory in European Politics: Identity, Policy and Governance, Palgrave Macmillan, Basingstoke, 2005, pp. 1-32.

[6] L. Phillips, M. Jorgensen, Discourse Analysis as a Theory and Method, Sage, London, 2002.

[7] D. Howarth, Discourse theory, in: D. Marsh, G. Stoker (Eds.), Theory and Methods in Political Science, Macmillan Press, Basingstoke, 1995, pp. 115-133.

[8] D. Howarth, Applying discourse theory: the method of articulation, in: D. Howarth, J. Torfing (Eds.), Discourse Theory in European Politics: Identity, Policy and Governance, Palgrave Macmillan, Basingstoke, 2005, pp. 1-32.

[9] D. Howarth, Y. Stavrakakis (Eds.), Discourse Theory and Political Analysis: Identities, Hegemonies and Social Change, Manchester University Press, Manchester, 2000.

[10] S. Phelan, L. Dahlberg, Discourse theory and critical media politics: an introduction, in: L. Dahlberg, S. Phelan (Eds.), Discourse Theory and Critical Media Politics, Palgrave Macmillan, Basingstoke, 2011, pp. 1-39.

[11] E. Laclau, C. Mouffe, Hegemony and Socialist Strategy: Towards a Radical Democratic Politics, Verso, London, 1985.

[12] E. Laclau, Metaphor and social antagonisms, in: C. Nelson, L. Grossberg (Eds.), Marxism and the Interpretation of Culture, Macmillan Education, Basingstoke, 1988, pp. 249-257.

[13] E. Laclau, New Reflections on the Revolution of Our Times, Verso, London, 1990.

[14] E. Laclau, Emancipation (s), Verso, London, 1996.

[15] N. Carpentier, B. De Cleen, Bringing discourse theory into media studies, Journal of Language and Politics 6 (2007) 265-293.

[16] N. Carpentier, E. Spinoy, Introduction. From the political to the cultural, in: N. Carpentier, E. Spinoy (Eds.), Discourse Theory and Cultural Analysis, Hampton Press, Cresskill, NJ, 2008, pp. 1-26.

[17] M. Hulme, Why We Disagree about Climate Change, Cambridge University Press, Cambridge, 2009.

[18] J. Torfing, New Theories of Discourse, Blackwell, Oxford, 1999.

[19] B. Adam, C. Groves, Future Matters, Action, Knowledge, Ethics, Brill, Leiden, 2007.

[20] E. Eide, R. Kunelius, Moment of hope, mode of realism, International Journal of Communication 6 (2012) 266285.

[21] J. Urry, Climate Change \& Society, Polity Press, Cambridge, 2011.

[22] M. Boykoff, Carbonundrums: the role of the media, in: S. Schneider, A. Rosencranz, M. Mastrandea, K. KuntzDuriseti (Eds.), Climate Change Science and Policy, Island Press, Washington, 2009, pp. 397-404.

[23] M. Boykoff, J. Smith, Media representations of climate change, in: C. Lever-Tracy (Ed.), Routledge Handbook of Climate Change and Society, Routledge, London \& New York, 2010, pp. 210-218.

[24] C. Lever-Tracy (Ed.), Routledge Handbook of Climate Change and Society, Routledge, London \& New York, 2010. 
[25] M. Giddens, The Politics of Climate Change, Polity Press, Cambridge, 2009.

[26] T. Boyce, J. Lewis (Eds.), Climate Change and the Media, Lang, New York, 2009.

[27] M. Boykoff, Who Speaks for the Climate? Cambridge University Press, Cambridge, 2011.

[28] K. Krippendorf, Content Analysis: An Introduction to its Methodology, Sage, Los Angeles, 2013.

[29] E. Eide, R. Kunelius, V. Kumpu (Eds.), Global Climate, Local Journalisms. A Transnational Study of How Media Make Sense of Climate Summits, Projekt Verlag, Bochum, 2010.

[30] E. Eide, R. Kunelius (Eds.), Media Meets Climate. The Global Challenge for Journalism, Go“ teborg, Nordicom, 2012 .

[31] E. Eide, A. Ytterstad, The tainted hero: frames of domestication in Norwegian press representation of the Bali climate summit, International Journal of Press/Politics 16 (2011) 50-74.

[32] P. Suhonen, Environmental issues, the Finnish major press, and public opinion, International Communication Gazette 51 (1993) 91-112.

[33] J. Lyytimäki, The Environment in the Headlines. Newspaper Coverage of Climate Change and Eutrophication in Finland, Edita Prima Ltd., Helsinki, 2012.

[34] J. Lyytimäki, Mainstreaming climate policy: the role of media coverage in Finland, Mitigation and Adaptation Strategies for Global Change 16 (2011) 649-661.

[35] H. Heikkila“ , R. Kunelius, Access, dialogue, deliberation. Experimenting with three concepts of journalism criticism, Nordicom Review 9 (1998) 71-84.

[36] V. Kumpu, R. Kunelius, Coming to terms with political realities? in: E. Eide, R. Kunelius, V. Kumpu (Eds.), Global Climate, Local Journalisms. A Transnational Study of How Media Make Sense of Climate Summits, Projekt Verlag, Bochum, 2010, pp. 179-194.

[37] Statistics Finland, Finnish Mass Media, Tilastokeskus, Helsinki, 2010.

[38] C. Sparks, Introduction: the panic over tabloid news, in: C. Sparks, J. Tulloch (Eds.), Tabloid Tales. Global Debates Over Media Standards, Rowman \& Littlefield, Lanham, 2000, pp. 1-40.

[39] P. Kivioja, Iltapa iva“lehdet mediakenta“n ja yhteiskunnan muutoksessa, Tampereen yliopisto, Tampere, 2008.

[40] I. Haavisto, EU vai ei? EVAn arvo- ja asennetutkimus 2010, Taloustieto, Helsinki, 2012.

[41] I. Haavisto, Tyo“ ela“ma”n kulttuurivallankumous, EVAn arvo- ja asennetutkimus, Yliopistopaino, Helsinki, 2012.

[42] M. Tegelberg, The dirty old man of climate politics? in: E. Eide, R. Kunelius, V. Kumpu (Eds.), Global Climate, Local Journalisms. A Transnational Study on How Media Make Sense of Climate Summits, Projekt Verlag, Bochum, 2010, pp. 97-114.

[43] P. Chubb, W. Bacon, Fiery politics and extreme events, in: E. Eide, R. Kunelius, V. Kumpu (Eds.), Global Climate, Local Journalisms. A Transnational Study on How Media Make Sense of Climate Summits, Projekt Verlag, Bochum, 2010, pp. 51-66.

[44] P. Chubb, Really, fundamentally wrong', the media coverage of the business campaign against the Australian carbon tax, in: E. Eide, R. Kunelius (Eds.), Media Meets Climate. The Global Challenge for Journalism, Go“" teborg, Nordicom, 2012, pp. 179-194.

[45] D. Yagodin, Listening to the wind. Clientelism and climate change, in: E. Eide, R. Kunelius, V. Kumpu (Eds.), Global Climate, Local Journalisms. A Transnational Study on How Media Make Sense of Climate Summits, Projekt Verlag, Bochum, 2010, pp. 275-290.

[46] M. Rhaman, A metaphor for the world, in: E. Eide, R. Kunelius, V. Kumpu (Eds.), Global Climate, Local Journalisms. A Transnational Study on How Media Make Sense of Climate Summits, Projekt Verlag, Bochum, 2010, pp. 67-82.

[47] M. Rhaman, Applying advocacy in climate change. The case of Bangladesh, in: E. Eide, R. Kunelius (Eds.), Media Meets Climate. The Global Challenge for Journalism, Nordicom, Goteborg, 2012, pp. 145-162. 